\title{
Photosynthesis-irradiance relationships in natural phytoplankton populations of the Barents Sea
}

\author{
FRANCISCO REY
}

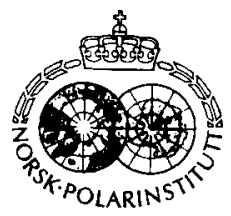

Rey, F. 1991: Photosynthesis-irradiance relationships in natural phytoplankton populations of the Barents Sea. Pp.105-116 in Sakshaug, E., Hopkins, C. C. E. \& Øritsland, N. A. (eds.): Proceedings of the Pro Mare Symposium on Polar Marine Ecology, Trondheim, 12-16 May 1990. Polar Research 10(1).

An analysis is made of the photosynthesis-irradiance relationships in natural phytoplankton populations in the Barents Sea. The data set comprises 232 experiments carried out during a 10-year period, both in open and ice-covered waters. The variability on the $\mathbf{P}-\mathbf{I}$ parameters is discussed and examined in relation to the variation in a variety of environmental conditions. The results suggest that in the Barents Sca, as in other Arctic areas, phytoplankton photosynthesis is mainly controlled by physical variables. However, control of the phytoplankton stock, i.e. by zooplankton grazing, seems also to have a considerable indirect influence on P-I parameters, especially after the spring bloom and the depletion of winter nutrients.

Francisco Rey, Institute of Marine Research, P.O. Box 1870 Nordnes, N-5024 Bergen, Norway (revised May 1991).

\section{Introduction}

As in other polar seas, phytoplankton in the Barents Sea are exposed to extreme seasonal variations of such environmental conditions as day length, available light, water column stability, and water temperature. Especially important is the fact that the Barents Sea is dominated by two different water masses: cold Arctic waters flowing in from the north and warmer Atlantic waters flowing in from the south, giving rise to a marked front. In addition, the northern half of the Barents Sea is seasonally covered by ice.

Since 1979, the Institute of Marine Research has carried out biological oceanographic investigations in the Barents Sea. Studies have been focused mainly on the feeding conditions of the capelin stock in order to elucidate the large annual and geographical variations in the growth of this fish species (Skjoldal \& Rey 1989). These investigations were incorporated into the Norwegian Research Program for Marine Arctic Ecology (Pro Mare) in 1984 and were concluded in 1989. During this period, a series of phytoplankton photosynthesis-irradiance experiments were carried out. The aim of these experiments was to characterise the primary production potential of the Barents Sea. The data set obtained from these experiments is presented here and analysed with respect to the relationships between the parameters of the photosynthesis-irradiance curve and other environmental parameters. For logis- tical reasons the bulk of the data was collected during the boreal spring and summer.

\section{Material and methods}

The data employed in this analysis of phytoplankton photosynthesis were derived from 232 photosynthesis-irradiance experiments carried out between 1980 and 1989. Samples represent different seasons, types of water masses, ice cover, and depths. The samples were usually taken from the upper mixed layer, the subsurface chlorophyll maximum (if present), and from below the pycnocline. Fig. 1 shows the location of the sampled stations while Table 1 presents an overview of the collected data.

Two types of incubators were used for measuring the uptake of radioactive carbon. The first, called the low-light incubator (LL), was equipped with daylight-type fluorescent tubes (OSRAM 19/ Daylight 5000 de Luxe) that, combined with neutral density plexiglass filters, gave ten different quantum scalar irradiances in the range from 0 to $390 \mu \mathrm{mol} \mathrm{m} \mathrm{m}^{-2} \mathrm{~s}^{-1}$. The sample volume was $100 \mathrm{ml}$ of seawater, to which $148 \mathrm{kBq}(4 \mu \mathrm{Ci})$ of radioactive carbon were added (The International Agency for ${ }^{14} \mathrm{C}$ Determination, Denmark). The incubation time was about 4 hours. The second incubator, a high-light type (HL), was equipped with an halogen-metal lamp (OSRAM Power 


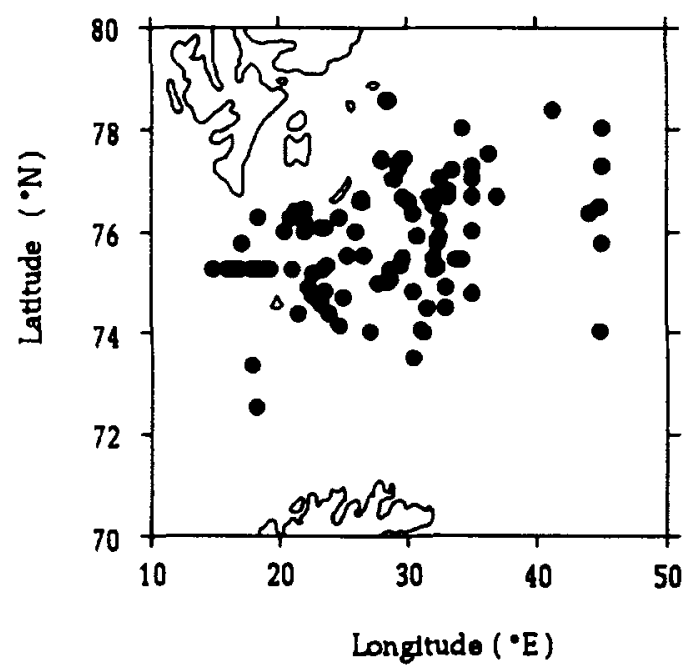

Fig. 1. Station locations in the Barents Sea.

Star, $400 \mathrm{~W}$ ) that, combined with neutral density filters, gave 11 different intensities in the range from 0 to $1700 \mu \mathrm{mol} \mathrm{m}^{-2} \mathrm{~s}^{-1}$ of quantum scalar irradiance. To a sample volume of about $300 \mathrm{ml}$. about $1480 \mathrm{kBq}(40 \mu \mathrm{Ci})$ was added. After gentle mixing, $20 \mathrm{ml}$ aliquots were poured into Pyrex bottles with an automatic dispenser and incubated for about 2 hours. When working in open sea areas, the temperature in the incubators was kept at in situ temperature by a continuous flow of subsurface seawater (about $4 \mathrm{~m}$ depth). In icecovered waters and in front areas, the temperature in the incubators was maintained at $\pm 1^{\circ} \mathrm{C}$ of the in situ temperature by means of a thermostat-controlled water bath. In all cases, incubation was terminated by immediate filtration through Millipore membrane filters of $0.45 \mu \mathrm{m}$ pore size. Thereafter, the filters were either kept frozen at $-18^{\circ} \mathrm{C}$ for further treatment ashore or analysed on board. The filters were fumed for 15 minutes with concentrated hydrochloric acid, after which $7 \mathrm{ml}$ of InstaGel (up to 1986) or OptiFluor was added. The radioactivity on the filters was measured with a Packard Tri Carb scintillation spectrometer using the channel-ratio method for estimating counting efficiency. The photosynthesis-irradiance curve parameters were estimated using the model described by Platt et al. (1980):

$$
\mathrm{P}^{\mathrm{B}}=\mathrm{P}_{\mathrm{s}}^{\mathrm{B}}\left(1-\mathrm{e}^{-\alpha^{B} \mathrm{I}} / \mathrm{P}_{\mathrm{s}}^{\mathrm{B}}\right) \mathrm{e}^{-\beta^{B} I} / \mathrm{P}_{\mathrm{s}}^{\mathrm{B}}
$$

$\mathrm{P}^{\mathrm{B}}$ : photosynthetic rate $\left[\mathrm{mgC}(\mathrm{mgChl})^{-1} \mathrm{~h}^{-1}\right.$ ]

$P_{5}^{B}$ : light-saturated photosynthetic rate in the absence of photoinhibition [mgC $(\mathrm{mgChl})^{-1} \mathrm{~h}^{-1}$

$\alpha^{\mathrm{B}}$ : initial slope of the P-I curve [mgC $\left.(\mathrm{mgChl})^{-1} \mathrm{~h}^{-1}\left(\mu \mathrm{mol} \mathrm{m} \mathrm{m}^{-2} \mathrm{~s}^{-1}\right)^{-1}\right]$.

I: quantum scalar irradiance $\left(\mu \mathrm{mol} \mathrm{m} \mathrm{m}^{-2} \mathrm{~s}^{-1}\right)$

$\beta^{\mathrm{B}}$ : index of photoinhibition $\left[\mathrm{mgC}(\mathrm{mgChl})^{-1} \mathrm{~h}^{-1}\right.$ $\left.\left(\mu \mathrm{mol} \mathrm{m}{ }^{-2} \mathrm{~s}^{-1}\right)^{-1}\right]$

After fitting the equation to the data (Nelder \& Mead 1965), the following derived parameters were calculated (Platt et al. 1980):

$$
\begin{aligned}
& \mathrm{P}_{\mathrm{m}}^{\mathrm{B}}=\mathrm{P}_{\mathrm{s}}^{\mathrm{B}}\left[\alpha^{\mathrm{B}} /\left(\alpha^{\mathrm{B}}+\beta^{\mathrm{B}}\right)\right] \cdot\left[\beta^{\mathrm{B}} /\left(\alpha^{\mathrm{B}}+\beta^{\mathrm{B}}\right)\right]^{\beta \mathrm{B} / \alpha \mathrm{B}}, \\
& \text { the maximum observed photosynthetic } \\
& \text { rate }\left[\mathrm{mgC}(\mathrm{mgChl})^{-1} \mathrm{~h}^{-1}\right] \\
& I_{k}=P_{m}^{B} / \alpha^{B} \text {, an index of photoadaptation } \\
& \left(\mu \mathrm{mol} \mathrm{m} \mathrm{m}^{-2} \mathrm{~s}^{-1}\right)
\end{aligned}
$$

\begin{tabular}{|c|c|c|c|c|c|}
\hline Year & $\begin{array}{l}\text { Number of } \\
\text { observations }\end{array}$ & Month & $\begin{array}{l}\text { Sampling } \\
\text { depths (m) }\end{array}$ & $\begin{array}{l}\text { Incubator } \\
\text { type }\end{array}$ & $\begin{array}{l}\text { Main type of } \\
\text { watermasses }\end{array}$ \\
\hline 1980 & 3 & July & $5-35$ & LL & Open waters \\
\hline 1981 & 29 & May. July, August & $0-45$ & LL & Open waters \\
\hline 1982 & 8 & May. June & $0-30$ & LL & Open waters \\
\hline 1983 & 49 & May. June & $0-80$ & LL & $\begin{array}{l}\text { Ice-covered waters } \\
\text { Open waters }\end{array}$ \\
\hline 1984 & 37 & Junc. August & $5-57$ & LL & Open waters \\
\hline 1985 & 28 & August & $10-60$ & LL & Open waters \\
\hline 1986 & 27 & April & $0-50$ & $\mathrm{LL}$ & Ice-covered waters \\
\hline 1987 & 39 & February, May, June & $0-90$ & HL & $\begin{array}{l}\text { Ice-covered waters } \\
\text { Open waters }\end{array}$ \\
\hline 1989 & 12 & May & $0-100$ & HL & Open waters \\
\hline
\end{tabular}

Table 1. Overview of the data sets utilised

$\mathrm{LL}=$ Low-light incubator.

$\mathrm{HL}=$ High-light incubator . 
$\mathrm{I}_{\mathrm{m}}=\mathrm{P}_{\mathrm{s}}^{\mathrm{B}} / \alpha^{\mathrm{B}} \cdot \ln \left[\left(\alpha^{\mathrm{B}}+\beta^{\mathrm{B}}\right) / \beta^{\mathrm{B}}\right]$, the irradiance at which photosynthesis is at maximum $\left(\mu \mathrm{mol} \mathrm{m}{ }^{-2} \mathrm{~s}^{-1}\right)$

$\mathrm{I}_{\mathrm{b}}=\mathrm{P}_{\mathrm{s}}^{\mathrm{B}} / \beta^{\mathrm{B}}$, an index for photoinhibition susceptibility ( $\mu \mathrm{mol} \mathrm{m}{ }^{-2} \mathrm{~s}^{-1}$ )

Chlorophyll $a$ concentrations were determined by filtering known volumes of seawater through membrane filters of $0.45 \mu \mathrm{m}$ pore size. The filters were kept frozen for a few days and then dissolved in $90 \%$ acetone. The pigments were extracted overnight at $4^{\circ} \mathrm{C}$, centrifuged, and then their fluorescence was measured before and after acidification in a Turner Designs fluorometer. The fluorometer was calibrated against commercially purified chlorophyll $a$ (Sigma Chemical Co.).

Nutrients were measured onboard immediately after collection with standard methods adapted to an autoanalyser (Føyn et al. 1981).

\section{Results and discussion}

\section{Environmental parameters}

The average seasonal distribution of PAR (photosynthetically active radiation) at Bjørnøya $\left(74^{\circ} 15^{\prime} \mathrm{N}\right)$ which lies at the mean latitude of the Barents Sea is shown in Fig. 2. During the Arctic winter, incident light is hardly detectable. The first recordable light appears in mid-February and increases exponentially thereafter and reaches a maximum total daily irradiance in mid-June. The greatest temporal increase in incoming irradiance is usually observed in April. The average hourly irradiance, however, increases exponentially somewhat earlier than the total daily irradiance and levels off at the end of April.

Hydrographic conditions were extremely variable, ranging from relatively warm Atlantic waters of high salinity to cold Arctic water masses, in many cases near the freezing point. Fig. 3 shows the temperature-salinity relationships at the depths from where the water samples were collected. About $60 \%$ of the samples were collected either from Atlantic or Arctic Water proper and about $25 \%$ from meltwater. The remainder was collected in areas with different degrees of mixing between the main water masses.

\section{Variations in P-I parameters}

The frequency distributions of the parameters of the P-I curve for the whole investigated period are shown in Fig. 4A-E. For most of the parameters, a positive skewness of the values was evident, as has been found in previous polar investigations (Harrison \& Platt 1986).

$\mathrm{P}_{\mathrm{m}}^{\mathrm{B}}$ ranged from 0.27 to $7.3 \mathrm{mgC}(\mathrm{mgChl})^{-1} \mathrm{~h}^{-1}$ with a mean of $1.73 ; \alpha^{\mathrm{B}}$ ranged from 0.0037 to 0.1633 with a mean of $0.0440 \mathrm{mgC}(\mathrm{mgChl})^{-1} \mathrm{~h}^{-1}$

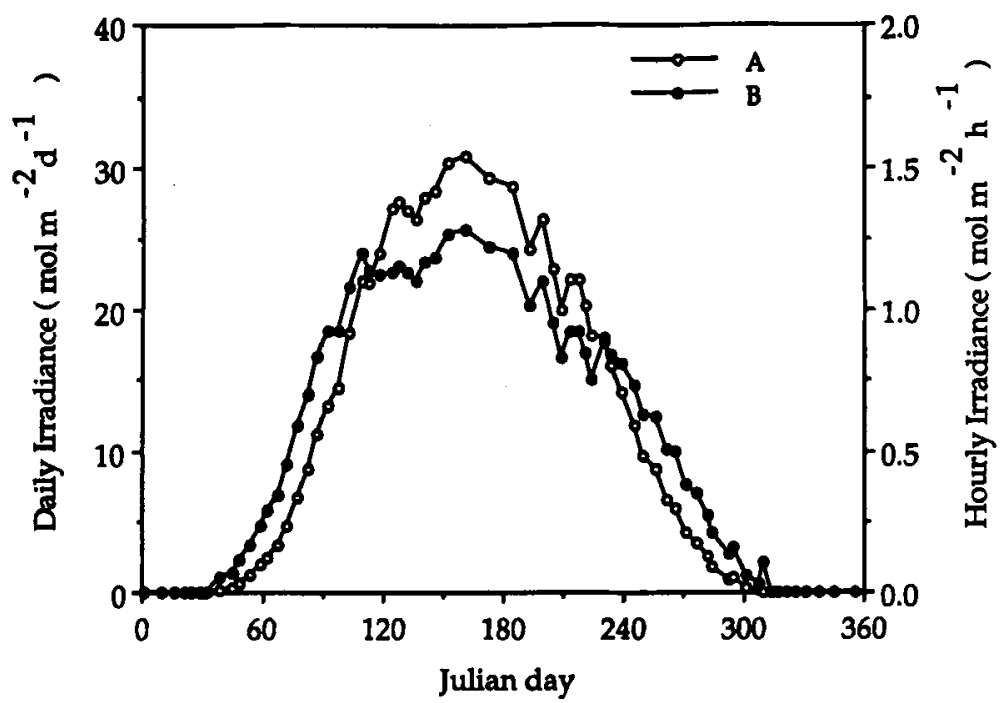

Fig. 2. Average (1970-1989) seasonal dístribution of photosynthetically active radiation (PAR) at Bjørnøya. A. Total daily irradiance. B. Average hourly irradiance (lit hours). 


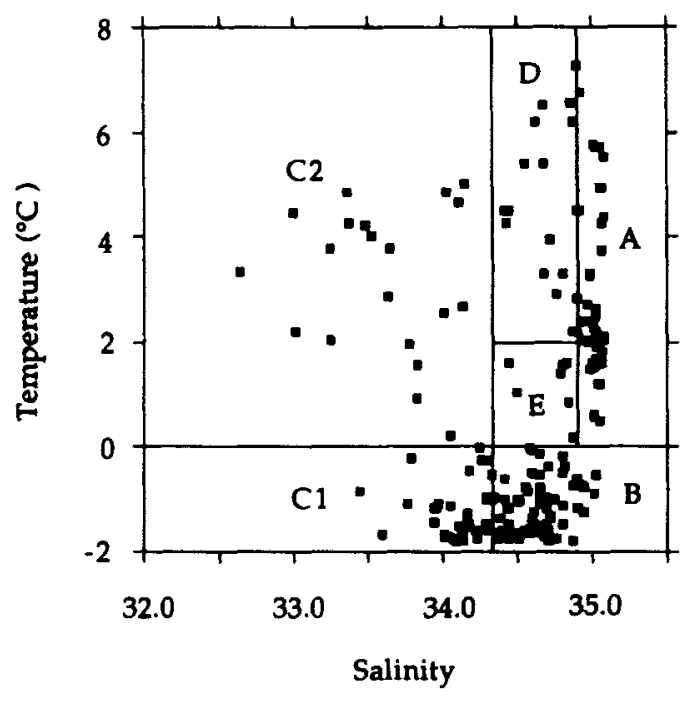

Fig. 3. Temperature-salinity relationships at the sampling depths: A. Atlantic Water: B. Arctic Water: Cl. Spring melt water: C2. Summer melt water: D. Mixcd Atlantic and meltwaters in summer/autumn; E. Mixed Atlantic and Arctic waters.

( $\left.\mu \mathrm{mol} \mathrm{m} \mathrm{m}^{-2} \mathrm{~s}^{-1}\right)^{-1} ; \beta^{\mathrm{B}}$ ranged from 0 to $1.085 \mathrm{mgC}$ $(\mathrm{mgChl})^{-1} \mathrm{~h}^{-1}\left(\mu \mathrm{mol} \mathrm{m} \mathrm{m}^{-2} \mathrm{~s}^{-1}\right)^{-1}$ with a mean of $0.0312 ; I_{m}$ ranged from 19 to $891 \mu \mathrm{mol} \mathrm{m}^{-2} \mathrm{~s}^{-1}$ with a mean of $190 ; I_{k}$ ranged from 4 to $319 \mu \mathrm{mol} \mathrm{m} \mathrm{m}^{-2} \mathrm{~s}^{-1}$ with a mean of $47 ; I_{b}$ ranged from 49 to infinite. For $\beta^{B}$ and $I_{b}$, the number of observations was reduced to 194 by excluding a series of experiments for which the light intensity of one of the incubators (LL) was not sufficient for obtaining a proper estimate of these parameters.

Harrison \& Platt (1986) found that high latitude phytoplankton populations exhibited lower values for $\mathrm{P}_{\mathrm{m}}^{\mathrm{B}}, \mathrm{I}_{\mathrm{in}}$ and $\mathrm{I}_{\mathrm{k}}$ as well as higher $\alpha^{\mathrm{B}}$ values than phytoplankton of temperate latitudes. Such differences were not always found in our data set. The median $\mathrm{P}_{\mathrm{m}}^{\mathrm{B}}$ for all samples was $1.60 \mathrm{mgC}$ $(\mathrm{mgChl})^{-1} \mathrm{~h}^{-1}$, which is somewhere between the median values of 1.21 and 2.39 found for Arctic and mid-latitudes in eastern Canada. The Barents Sea is an area typically characterised by cold Arctic waters in the north and relatively temperate Atlantic waters in the south. Assuming that the overall median value for the Barents Sea represents an "average" value for temperate and cold waters, the data set was divided into two groups representing temperatures above and below $0^{\circ} \mathrm{C}$ respectively. This temperature is commonly used as a boundary between Arctic and
Atlantic waters (Loeng 1989). A single ANOVA was then applied to determine if there were significant differences in the mean values of the P-I parameters between the two subgroups. Only $P_{m}^{B}$ and $I_{k}$ mean values were found to be significantly different at the $5 \%$ significance level. Mean $\mathrm{P}_{\mathrm{m}}^{\mathrm{B}}$ was 1.49 below $0^{\circ} \mathrm{C}$ and 2.01 above $0^{\circ} \mathrm{C}$. This is as expected when it is taken into consideration that the maximum photosynthetic rate of natural populations is usually a function of temperature. However, other factors such as species composition, cell size, and biomass might also have an influence on these differences. Mean $I_{k}$ values were 41 and $54 \mu \mathrm{mol} \mathrm{m} \mathrm{m}^{-2} \mathrm{~s}^{-1}$ for below and above $0^{\circ} \mathrm{C}$ samples, respectively, but this is probably mainly due to variations in $\mathbf{P}_{\mathrm{m}}^{\mathrm{B}}$. Means of the other parameters were not significantly different. $\alpha^{\text {B }}$. the other parameter determining $\mathrm{I}_{\mathrm{k}}$. which in the eastern Canadian Arctic was slightly larger at high latitudes (Harrison \& Platt 1986), showed similar mean values for both temperature ranges in the Barents Sea.

Although the range and median values of $\mathrm{P}_{\mathrm{m}}^{\mathrm{B}}$ in the Barents Sea were of the same magnitude as those found in the eastern Canadian Arctic, there were large differences in the $\alpha^{\mathrm{B}}$ values between the two regions. Assuming a solar irradiance conversion factor of $4.6 \mu \mathrm{mol} \mathrm{m}^{-2} \mathrm{~s}^{-1}$ $\left(\mathrm{W} \mathrm{m}^{-2}\right)^{-1}$, the Canadian Arctic values showed a median of $0.012 \mathrm{mgC}(\mathrm{mgChl})^{-1} \mathrm{~h}^{-1}(\mu \mathrm{mol}$ $\left.\mathrm{m}^{-2} \mathrm{~s}^{-1}\right)^{-1}$ compared to 0.037 in the Barents Sea, a difference of $3 \times$. This obviously affected also the differences found between the median $I_{k}$ values from both regions, i.e. $78 \mu \mathrm{mol} \mathrm{m} \mathrm{m}^{-2} \mathrm{~s}^{-1}$ for the Canadian Arctic versus 43 for the Barents Sea. Both data sets are large and include samples taken at different seasons, depths, and hydrographical and biological conditions, so if the differences in $\alpha^{B}$ and $I_{k}$ are real, these comparisons suggest that the natural phytoplankton populations of the Barents Sea may be more efficient in harvesting low light. The possibility of the effect of the different light sources utilised in the Canadian Arctic and the present work on $\alpha^{\mathrm{B}}$ and $I_{k}$ cannot be ruled out, since both parameters are influenced by the light spectral composition.

The values of the P-I parameters from the Barents Sea are in the same range as those reported from several investigations carried out in the Antarctic Ocean (Table 2). All the experiments in the Antarctic Ocean were carried out under controlled light conditions in laboratory incubators, with the exception of those of Sak- 

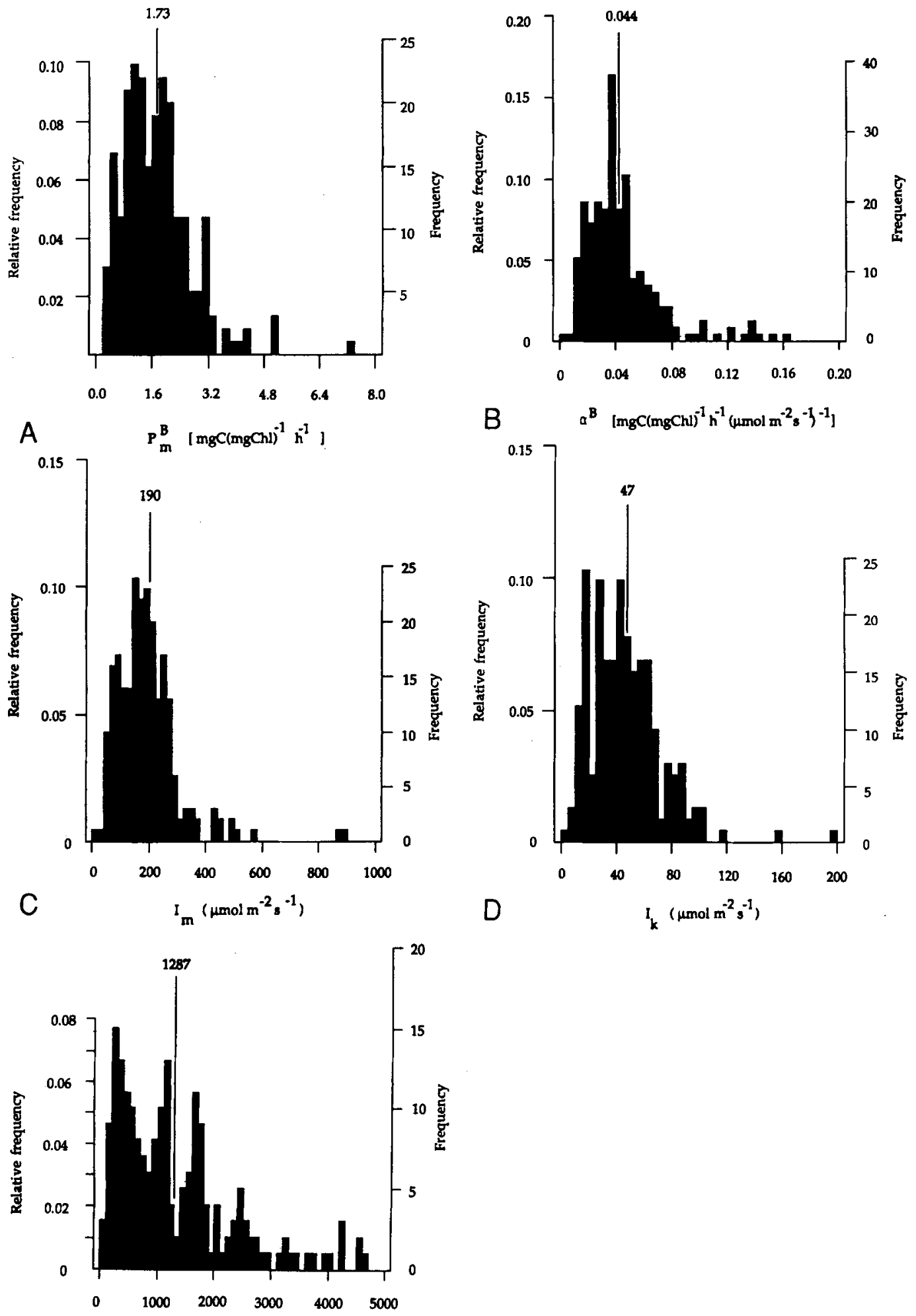

$E$

tb $\left(\mu \mathrm{mol} \mathrm{m} \mathrm{s}^{-1}\right)$

Fig. 4A-E. Frequency distribution of P-I parameters. Numerical values represent mean values. 
Table 2. P-l parameters of phytoplankton of selected polar arcas. (Means in parentheses).

\begin{tabular}{|c|c|c|c|c|c|c|}
\hline & $n$ & $\mathbf{P}_{m}^{8}$ & $\alpha^{B}$ & $I_{m}$ & $I_{h}$ & Reference \\
\hline $\begin{array}{l}\text { Antarctic } \\
\text { Isolated species }\end{array}$ & 3 & $\begin{array}{l}0.9-9.3 \\
(5.5)\end{array}$ & $\begin{array}{l}0.015-0.029 \\
(0.023)\end{array}$ & $\begin{array}{l}50-80 \\
(62)\end{array}$ & - & $\begin{array}{l}\text { Rivkin \& } \\
\text { Putt (1987) }\end{array}$ \\
\hline $\begin{array}{l}\text { Antarctic } \\
\text { Natural population } \\
\text { Early spring }\end{array}$ & 7 & $\begin{array}{l}2.8-3.7 \\
(3.1)\end{array}$ & $\begin{array}{l}0.064-0.075 \\
(0.069)\end{array}$ & - & $\begin{array}{l}42-49 \\
(45)\end{array}$ & $\begin{array}{l}\text { Rivkin } \\
\text { et at. (1989) }\end{array}$ \\
\hline $\begin{array}{l}\text { Antarctic } \\
\text { Natural population } \\
\text { Winter }\end{array}$ & 20 & $\begin{array}{l}0.2-2.4 \\
(1.2)\end{array}$ & $\begin{array}{l}0.006-0.066 \\
(0.026)\end{array}$ & $\begin{array}{l}58-530 \\
(219)\end{array}$ & $\begin{array}{l}34-177 \\
(54)\end{array}$ & $\begin{array}{l}\text { Brightman } \\
\text { \& Smith (1989) }\end{array}$ \\
\hline $\begin{array}{l}\text { Antarctic } \\
\text { Natural population } \\
\text { Summer }\end{array}$ & 8 & $\begin{array}{l}0.8-4.4 \\
(2.6)\end{array}$ & $\begin{array}{l}0.009-0.049 \\
(0.029)\end{array}$ & $\begin{array}{l}160-570 \\
(331)\end{array}$ & $\begin{array}{l}38-190 \\
(103)\end{array}$ & $\begin{array}{l}\text { Sakshaug \& } \\
\text { Holm-Hansen (1986) }\end{array}$ \\
\hline $\begin{array}{l}\text { Arctic } \\
\text { Natural population } \\
\text { All seasons }\end{array}$ & 276 & $1.2^{*}$ & $0.012^{*}$ & $368^{*}$ & $78^{*}$ & $\begin{array}{l}\text { Harrison \& } \\
\text { Platt (1986) }\end{array}$ \\
\hline $\begin{array}{l}\text { Arctic } \\
\text { Natural population } \\
\text { All seasons }\end{array}$ & 232 & $\begin{array}{l}0.3-7.3 \\
(1.7)\end{array}$ & $\begin{array}{l}0.004-0.163 \\
(0.044)\end{array}$ & $\begin{array}{l}19-891 \\
(190)\end{array}$ & $\begin{array}{l}+319 \\
(47)\end{array}$ & This work \\
\hline
\end{tabular}

\footnotetext{
* Median values

Units: $\mathrm{P}_{m}^{\mathrm{B}}: \operatorname{mgC}(\mathrm{mgChl})^{-1} \mathrm{~h}^{-1}$ $\alpha^{B}: \mathrm{mgC}(\mathrm{mgChl})^{-1} \mathrm{~h}^{-1}\left(\mu \mathrm{mol} \mathrm{m} \mathrm{m}^{-2} \mathrm{~s}^{-1}\right)^{-1}$. $\mathrm{I}_{\mathrm{m}}, \mathrm{I}_{\mathrm{k}}: \mu \mathrm{mol} \mathrm{m} \mathrm{m}^{-2} \mathrm{~s}^{-1}$.
}

shaug \& Holm-Hansen (1986) which were carried out under natural light on deck.

\section{Relationships between the $P-I$ parameters}

There is a pronounced correlation between $\mathrm{P}_{\mathrm{m}}^{\mathrm{B}}$ and $\alpha^{B}$ in both natural populations and laboratory cultures (Harding et al. 1981, 1985; MacCaull \& Platt, 1977; Harrison \& Platt 1986). This correlation is also evident in the Barents Sea although the scattering of values is high (Fig. 5), especially where $\alpha^{\mathbf{B}}$ values were higher than 0.1 . These values should be viewed with caution since they lie above the theoretical limit for $\alpha^{B}$ of phy. toplankton (Sakshaug \& Slagstad 1991 this volume). Values of $\alpha^{\mathrm{B}}$ lower than 0.1 showed a slightly better correlation with $\mathrm{P}_{\mathrm{m}}^{\mathrm{B}}$ at temperatures above $0^{\circ} \mathrm{C}$ than at below $0^{\circ} \mathrm{C}$.

$\mathrm{P}_{\mathrm{m}}^{\mathrm{B}}$. as expected from theoretical considerations, showed a slight positive correlation with both $I_{m}$ and $I_{k}$, although there was a large spread in the data. $\alpha^{\mathrm{B}}$, also as expected, was inversely correlated with the two above-mentioned light parameters (Fig. $6 \mathrm{~A}$ and $\mathrm{B}$ ). Neither $\mathrm{P}_{\mathrm{m}}^{\mathrm{B}}$ or $\alpha^{\mathrm{B}}$ were correlated with $\mathrm{I}_{\mathrm{b}}$.

\section{$P-I$ parameters and environmental factors}

Previous studies have shown that it is possible to assess the effect of environmental variables on

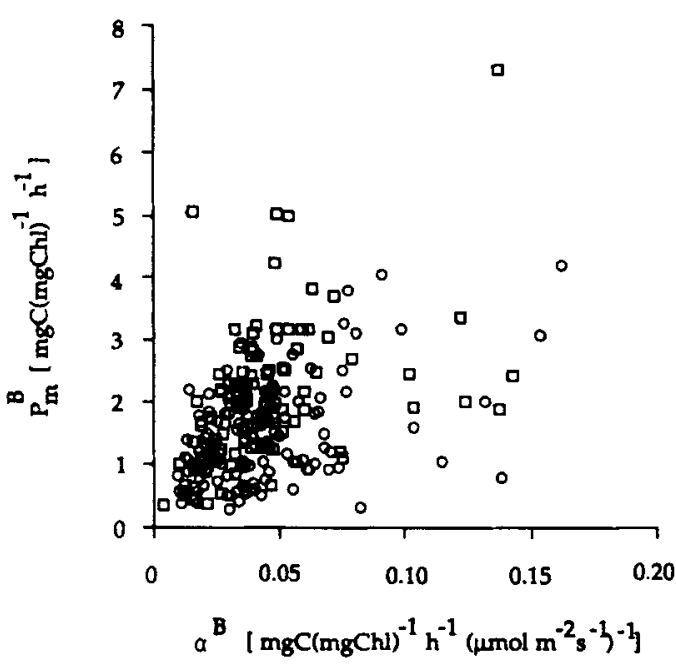

Fig. 5. Relationship between $\mathrm{P}_{\mathrm{m}}^{\mathrm{H}}$ and $\mathrm{o}^{\mathrm{B}}$ for samples taken below (circles) and above (squares) $0^{\circ} \mathrm{C}$. 

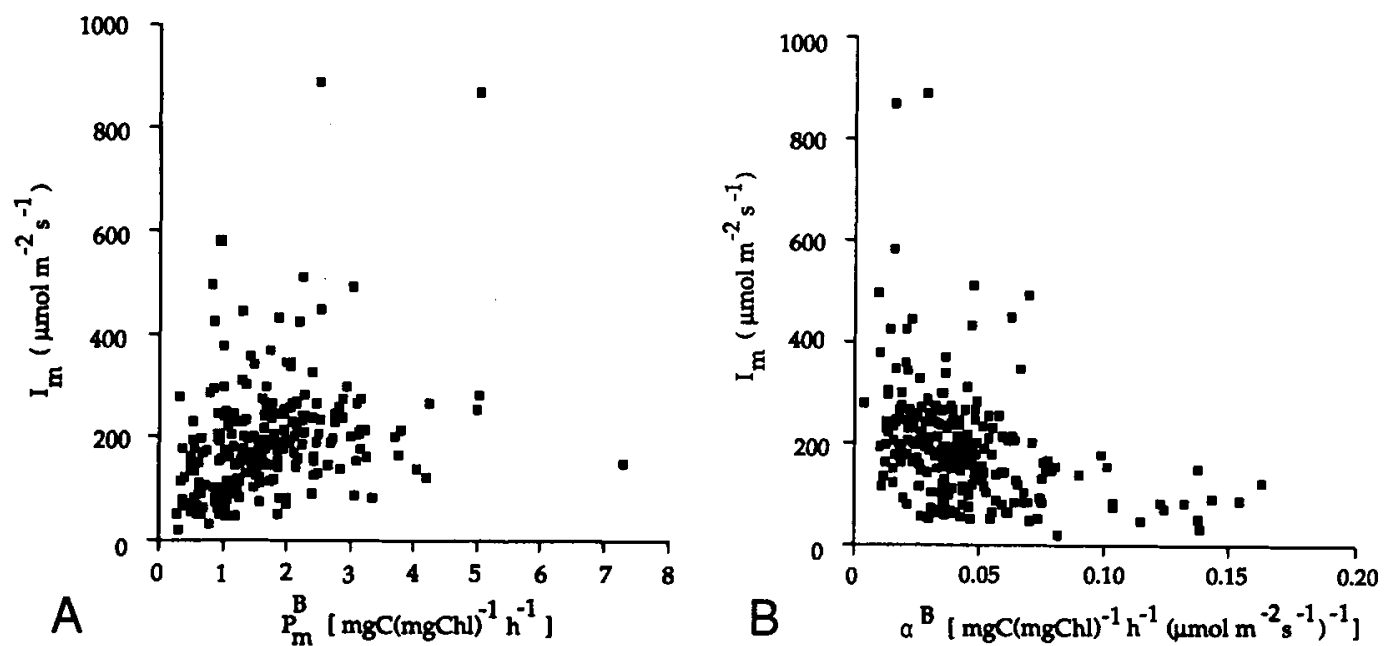

Fig. 6A-B. Relationships between two $\mathrm{P}-\mathbf{l}$ parameters.
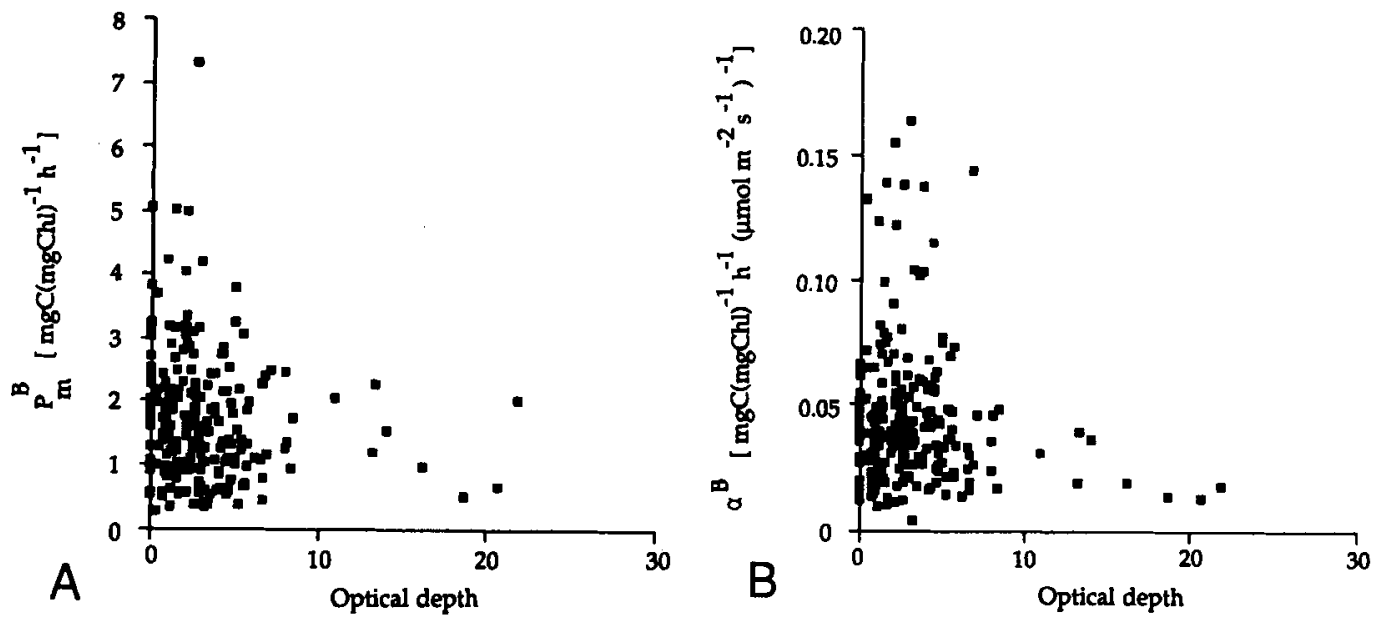

Fig. 6A-B. Relationships between two P-I parameters.
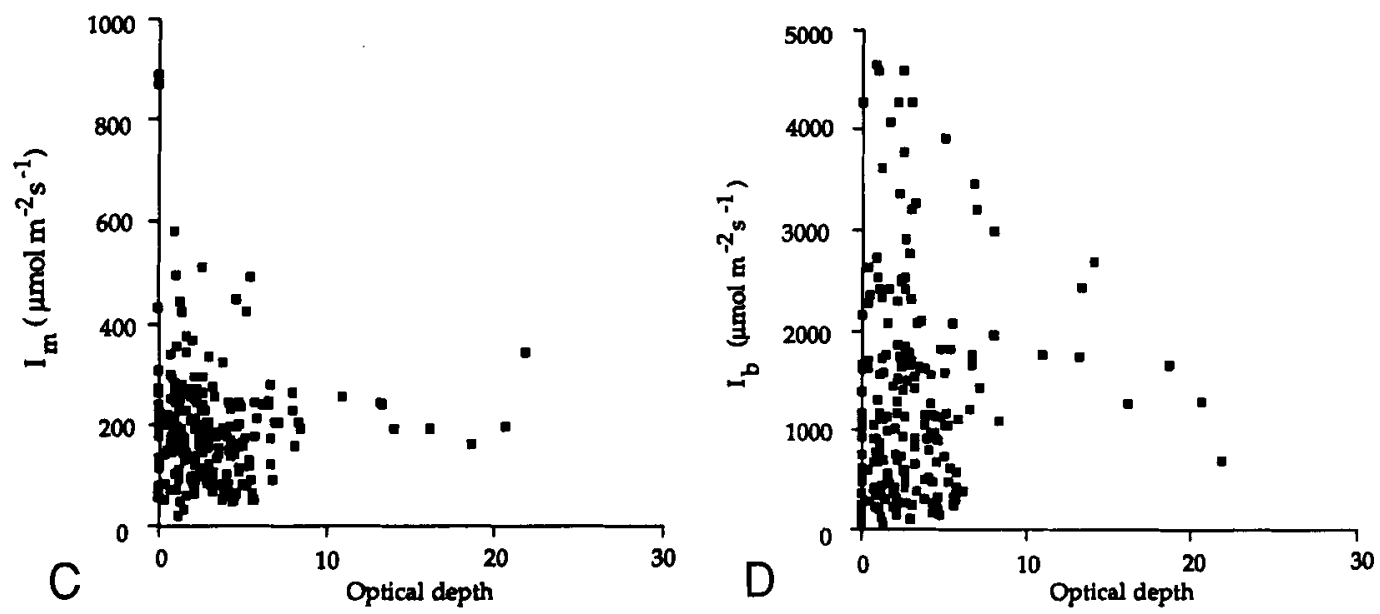

Fig. 7A-D. Relationships between the optical depth and P-I parameters. 
photosynthesis through their effect on the P-I parameters. $\mathrm{P}_{\mathrm{m}}^{\mathrm{B}}$, for example seems to be, on an annual basis, predominantly controlled by temperature, while $\alpha^{\mathrm{B}}$ is controlled by light history (Platt \& Jassby 1976: Harrison \& Platt 1980; Sakshaug et al. 1991). The same results have been found for phytoplankton growing in the laboratory (Mortain-Bertrand et al. 1988). The effect of temperature on the P-I parameters of natural phytoplankton populations of the Barents
Sea have already been commented upon above. With regard to light, since irradiance data for the whole set of P-I data was not available, the optical depth (sampling depth mean light attenuation coefficient at sampling station) has been chosen as an index of the light conditions at the sampling depths. None of the P-I parameters $\left(\mathrm{P}_{\mathrm{m}}^{\mathrm{B}}, \alpha^{\mathrm{B}}, \mathrm{I}_{\mathrm{m}}\right.$, $I_{k}$ or $I_{b}$ ) showed a clear relationship to optical depth. However, for all parameters except $I_{k}$, there was a general trend for maximum observed

Table 3. Simple rank correlation matrix of photosynthetic and environmental parameters. Barents Sca, 1980-1989. All coefficients based on 232 samples.

\begin{tabular}{|c|c|c|c|c|c|}
\hline & PBMAX & ALFA & BETA & IMAX & IK \\
\hline PBMAX & $1 .(\log x)$ & & & & \\
\hline ALFA & $0.4253 * 1$ & 1.0000 & & & \\
\hline BETA & $0.4067 * 1$ & 0.0397 & 1.00000 & & \\
\hline IMAX & $0.4(175 * 1$ & $-0.4264 * 1$ & $-0.1389 * 3$ & 1.00000 & \\
\hline IK & $0.4948 * 1$ & $-0.50+1 * 1$ & $0.3590 * 1$ & $0.8178 * 1$ & 1.0000 \\
\hline IB & -0.0622 & 0.0489 & $-0.9069 * 1$ & $0.3594 * 1$ & $-0.1426 * 3$ \\
\hline OPTDEPTH & $-0.1758 * 2$ & -0.0616 & -0.1103 & -0.1208 & -0.1277 \\
\hline TEMP & $0.2478 * 1$ & 0.0003 & $0.1360 * 3$ & $0.1677 * 3$ & $0.2315 * 1$ \\
\hline SALT & 0.0947 & -0.0680 & 0.11401 & 0.1083 & $0.19077^{* 2}$ \\
\hline NO3 & 0.0495 & $0.2075 * 2$ & 0.0484 & $-0.1889 * 2$ & $-0.1639 * 3$ \\
\hline $\mathrm{PO} 4$ & 0.0394 & $0.2052 \cdot 2$ & 0.06044 & $-0.2119 * 2$ & $-0.1810 * 2$ \\
\hline $\mathrm{SiO} 4$ & $0.1820 * 2$ & $0.1809 * 2$ & 0.0718 & -0.0436 & -0.0117 \\
\hline $\mathrm{NO} 3 / \mathrm{SiO} 4$ & -0.0289 & $0.1355 \cdot 3$ & -0.0107 & $-0.1729 * 2$ & $-0.1871 * 2$ \\
\hline CHLOR & -0.0528 & $-0.1939 * 2$ & -0.0075 & 0.1195 & 0.1249 \\
\hline PHAEOP & -0.0455 & -0.1183 & -0.0463 & 0.0741 & 0.0560 \\
\hline \multirow[t]{2}{*}{ PHAEOP/CHL } & 0.0111 & $0.1857 * 2$ & -0.0295 & $-0.1426 * 3$ & $-0.1746 * 2$ \\
\hline & IB & OPTDEPTH & TEMP & SALT & NO3 \\
\hline IB & 10000 & & & & \\
\hline OPTDEPTH & 0.0455 & 1.0000 & & & \\
\hline TEMP & -0.0457 & -0.0577 & 1.0000 & & \\
\hline SALT & -0.0351 & $0.2656 * 1$ & $0.3715 * 1$ & 1.00000 & \\
\hline NO3 & -0.0876 & $0.1666 \cdot 3$ & $-0.3482 * 1$ & $0.2499 * 1$ & 1.0000 \\
\hline PO4 & $-0,1070$ & $0.1577 * 3$ & $-0.3+13 * 1$ & $0.2557 * 1$ & $0.9525 * 1$ \\
\hline $\mathrm{SiO} 4$ & -0.0489 & 0.0410 & $-0.1321 * 3$ & $0.3240 * 1$ & $0.7665 * 1$ \\
\hline $\mathrm{NO} 3 / \mathrm{SiO}_{4}$ & -0.0214 & $0.3338 * 1$ & $-0.449 * 1$ & 0.1057 & $0.6965 * 1$ \\
\hline CHLOR & 0.01199 & $0.3246 \cdot 1$ & $-0.2348 * 1$ & $0.1789 * 2$ & -0.0184 \\
\hline PHAEOP & 0.0342 & $0.3434 * 1$ & $-0.1973 * 2$ & $0.1595 * 3$ & -0.0209 \\
\hline \multirow[t]{2}{*}{ PHAEOP/CHL } & -0.0005 & -0.0214 & 0.0140 & $-0.19014 * 2$ & -0.0018 \\
\hline & $\mathrm{PO} 4$ & $\mathrm{SiO} 4$ & $\mathrm{NO} 3 / \mathrm{SiO}_{4}$ & CHLOR & PHAEOP \\
\hline $\mathrm{PO} 4$ & $1.0 \times 00$ & & & & \\
\hline $\mathrm{SiO} 4$ & $0.7846 * 1$ & 1.00000 & & & \\
\hline $\mathrm{NO} / \mathrm{SiO} 4$ & $0.6543 * 1$ & $0.2940 * 1$ & $1.0(x)$ & & \\
\hline CHLOR & -0.0188 & -0.0280 & $0.2281 * 1$ & 1.0000 & \\
\hline PHAEOP & -0.0042 & 0.0107 & $0.2131 \cdot 2$ & $0.8084 * 1$ & 1.0000 \\
\hline \multirow[t]{2}{*}{ PHAEOP/CHL } & 0.0414 & 0.0130 & 0.00175 & $-0.4951 * 1$ & 0.0143 \\
\hline & PHAEOP CHL & & & & \\
\hline PHAEOP CHL & 1.00000 & & & & \\
\hline
\end{tabular}

$* 1=99.9 \%$ confidence level.

$\because 2=99.0 r_{i}$ confidence level.

$\because=95.0^{\circ}$ confidence level. 
values to decrease with increasing optical depth (Fig. 7A-D). Although the trend is strongly influenced by eight samples obtained at optical depths larger than 10 , these samples were collected in two different years (1985 and 1987), under quite different biological conditions (see below). It can then be assumed that the observed trend is real and not influenced by some common factor. The lack of correlation between $I_{k}$ and depth in high-latitude samples has also been observed by other authors (Platt et al. 1982; Harrison \& Platt 1986) and has been ascribed, together with smaller depth-related differences of the other P-I parameters, to the difference in the development of density stratification in high latitudes areas as compared with temperate regions.

In order to assess more qualitatively the influence of different environmental factors on the P-I parameters, a Spearman rank correlation analysis was carried out on the whole data set (Table 3). $\mathbf{P}_{m}^{B}$ was positively correlated with temperature and silicate, but negatively correlated with the optical depth. $\alpha^{B}$ was positively correlated with nutrients and a grazing index (phaeopigments/ chlorophyll) and negatively correlated with biomass (chlorophyll). $I_{m}$ and $I_{k}$ were positively correlated with hydrographic variables as temperature and salinity and negatively correlated with nutrients. When the data were analysed by seasons, some important differences appeared in the extent and nature of the environmental variables' effects on $P_{m}^{B}$. For example during winter (February-March), $\mathrm{P}_{\mathrm{m}}^{\mathrm{B}}$ was negatively correlated with temperature but started to show a positive correlation in spring (May-early June), exhibiting the strongest correlation during the summer months (July-August). The oppostie was seen in the correlation of $\mathrm{P}_{\mathrm{m}}^{\mathrm{B}}$ with the optical depth, being positively correlated in winter and early spring (April) and negatively correlated during spring and summer. The relationship between $\alpha^{\mathrm{B}}$ and other environmental factors did not show such marked differences from season to season. However, the relative strength of the different correlations changed from one season to another, with nutrients being more important in the spring and the grazing index during summer. With the exception of the influence of temperature on $\mathrm{P}_{\mathrm{m}}^{\mathrm{B}}$ that occurred through all seasons, no other environmental variable showed such strong correlation with the P-I parameters. The same lack of strong correlation between $\mathrm{P}-\mathrm{I}$ parameters and environmental variables has been observed in other regions (Harrison \& Platt 1986).

A more quantitative assessment of the importance of the environmental variables on $\mathrm{P}-\mathrm{I}$ parameters can be obtained by using stepwise multiple regression analysis (Harrison \& Platt $1980,1986)$. For this purpose the following environmental parameters were selected: temperature (as an hydrographic variable), chlorophyll (to represent phytoplankton biomass), nitrate (for nutrients), optical depth (for light conditions), the ratio between phaeopigments and chlorophyll (to represent grazing impact), and the ratio between nitrate and silicate (to represent main dominating phytoplankton groups; Skjoldal \& Rey 1989). Table 4 summarises the results of these regression analyses using $\mathrm{P}_{\mathrm{m}}^{\mathrm{B}}$ and $\alpha^{\mathrm{B}}$ as the dependent variables for the whole data set. Temperature and the phaeopigments/chlorophyll ratio were found to be the main variables controlling $\mathrm{P}_{\mathrm{m}}^{\mathrm{B}}$, although together they explained just $17 \%$ of the variation. The other four selected parameters explained only an additional $6 \%$. For $\alpha^{\mathrm{B}}$, the phaeopigment/ chlorophyll ratio explained $8.5 \%$ of the total variation with nitrate as a second important variable with about $3 \%$. The rest of the variables accounted only for $3 \%$ of the total variation.

As in the rank correlation analysis there were also large seasonal variations in the contribution of the different selected parameters in explaining variations of $\mathrm{P}_{\mathrm{m}}^{\mathrm{B}}$ or $\alpha^{\mathrm{B}}$. During winter $(\mathrm{n}=8)$.

Table 4. Stepwise multiple regression analysis of $\mathbf{P}_{\mathrm{m}}^{\mathrm{B}}$ and $\alpha^{\mathrm{B}}$ on selected biological and environmental variables. Based on 232 samples.

\begin{tabular}{lllll}
\hline $\begin{array}{l}\mathrm{P}_{\mathrm{m}}^{\mathrm{B}} \\
\text { Variable }\end{array}$ & Multiple R & $\mathrm{MR}^{2}$ & Delta $\mathrm{R}^{2}$ & F-ratio \\
\hline Temperature & 0.297 & 0.088 & 0.088 & 22.28 \\
Phaeop/Chl & 0.413 & 0.171 & 0.083 & 23.58 \\
Optical depth & 0.440 & 0.194 & 0.023 & 18.24 \\
Nitrate & 0.460 & 0.212 & 0.019 & 15.26 \\
Chlorophyll & 0.491 & 0.241 & 0.029 & 14.32 \\
Nitrate/silicate & 0.493 & 0.243 & 0.002 & 12.06 \\
$\alpha^{\mathrm{B}}$ & & & & \\
Phaeop/Chl & 0.291 & 0.085 & 0.085 & 21.23 \\
Nitrate & 0.334 & 0.112 & 0.027 & 14.40 \\
Optical depth & 0.361 & 0.130 & 0.018 & 11.35 \\
Temperature & 0.371 & 0.138 & 0.008 & 9.07 \\
Chlorophyll & 0.372 & 0.139 & 0.001 & 7.27 \\
Nitrate/silicatc & 0.374 & 0.140 & 0.001 & 6.09 \\
\hline
\end{tabular}


nutrients and biomass accounted for about $75 \%$ of the variations in $\mathrm{P}_{\mathrm{m}}^{\mathrm{B}}$ while biomass and temperature were responsible for about $28 \%$ of the variations in early spring $(n=27)$. In spring ( $n=$ 133), temperature and optical depth accounted for about $14 \%$ of the variations and the ratio phaeopigments/chlorophyll and temperature were responsible for $52 \%$ of the variations during summer $(n=64)$. These results suggest a seasonally increasing influence of temperature on the photosynthetic capacity of the phytoplankton in the Barents Sea. This is probably related to the increasing difference in temperature between the shallow upper mixed layer and the layers below the pycnocline that occurs throughout the spring and summer, especially in waters that have been covered by ice during winter.

In the case of $\alpha^{\mathrm{B}}$. biomass and the ratio phaeopigments/chlorophyll contributed $61 \%$ and $35 \%$ of the variation, respectively, during winter and early spring. In spring the variables responsible for most of the variation were the optical depth and nitrate, accounting for just $10 \%$. In summer, the optical depth, the ratio phaeopigments/chlorophyll, and temperature contributed about $30 \%$ to the variation. The importance of the light history (i.e. optical depth) in controlling $\alpha^{B}$, as it has been found in other investigations (Platt \& Jassby 1976), was not evi- dent until spring and was almost negligible on a several year basis. The same lack of relationship has been found earlier (Harrison \& Platt 1986). The relatively large importance of the ratio phaeopigments/chlorophyll as one of the variables determining a sustantial part of the variations of $\mathrm{P}_{\mathrm{m}}^{\mathrm{B}}$ and $\alpha^{\mathrm{B}}$, both on an annual and a seasonal basis, has not been described before for Arctic phytoplankton, probably because it has not been included in the analyses. The relative amount of phaeopigments has been suggested as an index of grazing pressure by herbivore zooplankton on phytoplankton (Shuman \& Lorenzen 1975; Welschmeyer \& Lorenzen 1985), but little is known about how it can affect phytoplankton photosynthesis. Most probably the effect is indirect, either through the recycling of nutrients or the reduction of biomass. Côté \& Platt (1983), working in a small marine inlet, also found a strong positive correlation between the phaeopigment/chlorophyll ratio and $\mathrm{P}_{\mathrm{m}}^{\mathrm{B}}$ and emphasised the importance of nutrient recycling in that coastal area. Kristiansen \& Lund (1989) found that in the Barents Sea ammonium was the most important nitrogen source for phytoplankton in late spring and summer. This period is characterised by a well-developed pycnocline that gives rise to an upper oligotrophic layer with phytoplankton growth supported by remin-

Table 5. Mean values and standard deviation (in parentheses) of photosynthetic parameters and environmental variables from two biological situations in the Barents Sea.

\begin{tabular}{|c|c|c|c|c|c|c|c|c|}
\hline Depth strata & Temperature & Chlorophyll & $P_{m}^{B}$ & $\frac{P_{m}^{C}}{{ }^{C} 10^{-2}}$ & $\alpha^{B}$ & $\begin{array}{c}\alpha^{C} \\
* 10^{-3}\end{array}$ & $1_{m}$ & $J_{k}$ \\
\hline \multicolumn{9}{|c|}{ May-June 1987} \\
\hline $\begin{array}{l}10 \text { metre } \\
\mathrm{n}=12\end{array}$ & $\begin{array}{c}0.70 \\
(-1.48-2.12)^{*}\end{array}$ & $\begin{array}{c}2.638 \\
(2.010)\end{array}$ & $\begin{array}{c}1.452 \\
(0.708)\end{array}$ & $\begin{array}{c}2.53 \\
(1.24)\end{array}$ & $\begin{array}{c}0.0244 \\
(0.0139)\end{array}$ & $\begin{array}{c}0.43 \\
(0.24)\end{array}$ & $\begin{array}{l}280 \\
(88)\end{array}$ & $\begin{array}{c}65 \\
(19)\end{array}$ \\
\hline $\begin{array}{l}30 \text { metre } \\
n=7\end{array}$ & $\begin{array}{c}1.10 \\
(-0.61-2.05)^{*}\end{array}$ & $\begin{array}{c}3.571 \\
(1.138)\end{array}$ & $\begin{array}{c}1.455 \\
(0.751)\end{array}$ & $\begin{array}{l}2.56 \\
(1.31)\end{array}$ & $\begin{array}{c}0.0275 \\
(0.0133)\end{array}$ & $\begin{array}{c}0.48 \\
(0.23)\end{array}$ & $\begin{array}{l}228 \\
(48)\end{array}$ & $\begin{array}{c}58 \\
(21)\end{array}$ \\
\hline $\begin{array}{l}>40 \text { metre } \\
n=12\end{array}$ & $\begin{array}{c}0.98 \\
(-0.79-2.03)\end{array}$ & $\begin{array}{c}3.283 \\
(1.362)\end{array}$ & $\begin{array}{c}0.962 \\
(0.549)\end{array}$ & $\begin{array}{c}1.68 \\
(0.96)\end{array}$ & $\begin{array}{c}0.0206 \\
(0.0085)\end{array}$ & $\begin{array}{c}0.36 \\
(0.15)\end{array}$ & $\begin{array}{l}179 \\
(48)\end{array}$ & $\begin{array}{c}46 \\
(14)\end{array}$ \\
\hline \multicolumn{9}{|l|}{ August 1985} \\
\hline $\begin{array}{l}10 \text { metre } \\
n=8\end{array}$ & $\begin{array}{c}3.81 \\
(2.03-5.39)^{*}\end{array}$ & $\begin{array}{c}0.346 \\
(0.176)\end{array}$ & $\begin{array}{c}1.735 \\
(0.365)\end{array}$ & $\begin{array}{c}2.34 \\
(0.49)\end{array}$ & $\begin{array}{c}0.0348 \\
(0.0090)\end{array}$ & $\begin{array}{c}0.47 \\
(0.12)\end{array}$ & $\begin{array}{l}214 \\
(37)\end{array}$ & $\begin{array}{c}53 \\
(18)\end{array}$ \\
\hline $\begin{array}{l}20-30 \text { metre } \\
n=8\end{array}$ & $\begin{array}{c}0.20 \\
(-1.74-6.48)^{*}\end{array}$ & $\begin{array}{c}0.886 \\
(0.492)\end{array}$ & $\begin{array}{c}1.295 \\
(0.480)\end{array}$ & $\begin{array}{c}2.46 \\
(0.87)\end{array}$ & $\begin{array}{c}0.0347 \\
(0.0107)\end{array}$ & $\begin{array}{c}0.66 \\
(0.17)\end{array}$ & $\begin{array}{c}189 \\
(103)\end{array}$ & $\begin{array}{c}38 \\
(11)\end{array}$ \\
\hline 3i-40 metre & -0.91 & 1.789 & 1.283 & 3.40 & 0.0561 & 1.48 & 111 & 22 \\
\hline $\mathrm{n}=8$ & $(-1.78-2.83)^{*}$ & $(1.451)$ & $(1.253)$ & $(3.67)$ & $(0.0458)$ & $(1.37)$ & $\begin{array}{c}(39) \\
03\end{array}$ & (6) \\
\hline $\begin{array}{l}>41 \text { metre } \\
n=4\end{array}$ & $\begin{array}{c}0.94 \\
(0.74-1.09)^{*}\end{array}$ & $\begin{array}{c}0.823 \\
(0.464)\end{array}$ & $\begin{array}{c}0.937 \\
(0.171)\end{array}$ & $\begin{array}{c}4.05 \\
(1.01)\end{array}$ & $\begin{array}{c}0.0526 \\
(0.0186)\end{array}$ & $\begin{array}{c}2.31 \\
(0.97)\end{array}$ & $\begin{array}{c}93 \\
(13)\end{array}$ & $\begin{array}{l}19 \\
(5)\end{array}$ \\
\hline
\end{tabular}

* Range. 
eralised nutrients (Rey \& Loeng 1985). Under these conditions, the effects of grazing on nutrient recycling could be of major importance in controlling phytoplankton photosynthesis in the Barents Sea after the spring bloom and the strengthening of the pycnocline. The fact that phytoplankton in this area is not severely nitrogen limited (Kristiansen \& Lund 1989) supports this idea.

On an overall basis neither biomass, nutrients, nor phytoplankton species composition seemed to have any major influence on controlling the variations in the $\mathrm{P}-\mathrm{I}$ parameters. The same was observed by Harrison \& Platt (1986) while working with phytoplankton populations in the eastern Canadian Arctic. These authors found their results to be consistent with nutrient studies that showed no signs of nutrient-stress.

In general, the results of this analysis of the PI parameters in the Barents Sea confirm previous findings in other Arctic regions (Harrison \& Platt 1986), i.e. the general lack of strong correlation between the P-I parameters and covarying environmental factors and the clear correlation between $\mathrm{P}_{\mathrm{m}}^{\mathrm{B}}$ and $\alpha^{\mathrm{B}}$. The main difference was that light did not have a clear role in determining variations in the photosynthetic efficiency, $\alpha^{B}$, as it had been previously suggested. However, it is inevitable that when working with such large sets of data some single relationships become masked and do not appear as significant. This is demonstrated in Table 5, where P-I parameters have been summarised along with some environmental factors from two different biological situations: in the spring of 1987 at the end of the phytoplankton bloom, dominated by the prymnesiophyte Phaeocystis pouchetii (Wassmann et al. 1990); and in the summer of 1985 after oligotrophic conditions have developed in the upper layer and a strong subsurface chlorophyll maximum has developed (Rey unpubl. data). During the spring situation, there were no differences in the P-I parameters with depth in the euphotic zone, with the exception of $I_{m}$ that decreased with depth. Below the euphotic zone (>40 m depth), only small differences in the P-I parameters were observed. This indicates that no adaptation to low irradiance had occurred, probably due to a strong vertical mixing. In the summer the situation was completely different. The chlorophyll normalised PI parameters were similar throughout the upper 30 metres, but they showed a sharp increase in $\alpha^{B}$ at the region of the subsurface chlorophyll maximum and below, while $P_{m}^{B}, I_{m}$ and $I_{k}$ decreased with depth. This supports the findings of Beardall \& Morris (1976) that a diatom growing at low intensities has enhanced ability to utilise sub-optimal intensities and reduced ability to utilise saturating levels. The most dramatic difference, however, was found in the carbon normalised P-I parameters. Both $\mathrm{P}_{\mathrm{m}}^{\mathrm{C}}$ and $\alpha^{\mathrm{C}}$ increased strongly with depth below the euphotic zone, suggesting that one of the mechanisms by which the phytoplankton adapted to the low light levels was increasing their cellular concentrations of photosynthetic pigments. These findings illustrate small scale effects on the P-I parameters, such as light adaptation, which may not always be revealed in a global analysis as the one made here.

Acknowledgements. - Sincere thanks to F. Mora for his help in collecting and processing the data. My gratitude also to B. Stensholt for advice in statistical matters and to E. Sakshaug for providing valuable comments. Thanks are also due to two anonymous reviewers for their helpful suggestions. This work was partially supported by the Norwegian Fisheries Research Council.

\section{References}

Beardall, J. \& Morris. I. 1976: The concept of light intensity adaptation in marine phytoplankton: some experiments with Phaeodactylum tricornutum. Mar. Biol. 37, 377-387.

Brightman, R. I. \& Smith, W. O., Jr. 1989: Photosynthesisirradiance relationships of antarctic phytoplankton during austral winter. Mar. Ecol. Prog. Ser. 53, 143-151.

Côté, B. \& Platt. T, 1983: Day-to-day variations in the springsummer photosynthetic parameters of coastal marine phytoplankton. Limnol. Oceanogr. 28, 320-344.

Føyn, L., Magnussen, M. \& Seglem, K. 1981: Automatic analysis of nutrients with 'on-line' data treatment. A presentation of the construction and performing of the system in use at the Institute of Marine Research vessels and laboratory. Fisken Hav., Serie B, 1981(4), 1-39.

Harding, L. W., Jr., Meeson, B. W., Prézelin, B. B. \& Sweeney, B. M. 1981: Diel periodicity of photosynthesis in marine phytoplankton. Mar. Biol. 61, 95-105.

Harding. L. W., Jr., Meeson. B. W. \& Fisher, T. R., Jr. 1985: Photosynthesis patterns in Chesapeake Bay phytoplankton: short- and long-term responses of P-I curve parameters to light. Mar. Ecol. Prog. Ser. 26, 99-111.

Harrison, W. G. \& Platt. T. 1980: Variations in assimilation number of coastal marine phytoplankton: Effects of environmental co-variates. J. Plankton Res. 2, 249-260.

Harrison, W. G. \& Platt, T. 1986: Photosynthesis-Irradiance relationships in polar and temperate phytoplankton populations. Polar Biol. 5, 153-164.

Kristiansen, S. \& Lund, B.Aa. 1989: Nitrogen cycling in the Barents Sea-I. Uptake of nitrogen in the water column: DeepSea Res. 36, 255-268. 
Loeng. H. 1989: Ecological features of the Barents Sea. Pp. 366-401 in Rey. L. \& Alexander. V. (eds.): Proceedings of the Sixth Conference of the Comite A rctique International. 1.315 May 1985. E. J. Brill. Leiden.

MacCaull, W. A. \& Platt. T. 1977: Diel variations in the photosynthetic parameters of coastal marine phytoplankton. Limnol. Oceanogr. 22. 723-731.

Mortain-Bertrand. A.. Descolas-Gros, C. \& Jupin, H. 1988: Growth. photosynthesis and carbon metabolism in the temperate marine diatom Skeletonema costatum adapted to low temperature and low photon-flux density. Mar. Biol. 100 . 135-141.

Nelder. J. A. \& Mead. R. 1965: A simplex method for function minimization. Computer J. 7. 308-313.

Platt. T. \& Jassby. A. 1976: The relationship between photosynthesis and light for natural assemblages of coastal marine phytoplankton. J. Phycol. 12, 421-430.

Platt. T.. Gallegos. C. L. \& Harrison, W. G. 1980: Photoinhibition of photosynthesis in natural assemblages of marine phytoplankton. J. Mar. Res. 38. 687-701.

Platt. T. . Harrison. W. G. Irwin. B.. Horne. E. P. \& Gallegos. C. L. 1982: Photosynthesis and photoadaptation of marinc phytoplankion in the Arctic. Deep-Sea Res. 29. 1159-1170.

Rey, F. \& Loeng. H. 1985: The influence of ice and hydrographic conditions on the development of phytoplankton in the Barents Sea. Pp. 49-63 in Gray. J. S. \& Christiansen. M. E. (eds.): Marine Biology of Polar Regions and Effects of Stress on Marine Organisms. John Wiley \& Sons Ltd. England.

Rivkin. R. B. \& Putt. M. 1987: Photosynthesis and cell division by antarctic microalgae: comparison of benthic. planktonic and ice algae. J. Phycol. 23. 223-229

Rivkin, R. B., Putt, M., Alexander. S. P., Meritt. D. \& Gaudet.
L. 1989: Biomass and production in polar planktonic and sea ice microbial communities: a comparative study. Mar. Biol. 101. 273-283

Sakshaug. E. \& Holm-Hansen, O. 1986: Photoadaptation in Antarctic phytoplankton: variations in growth rate, chemical composition and P versus I curves. J. Plankion Res, 8, 459 473

Sakshaug. E. \& Slagstad. D. 1991: Light and productivity of phytoplankton in polar marine ecosystems: a physiological view. Pp. 69-85 in Sakshaug, E., Hopkins, C. C. E. \& Øritsland. N. A. (eds.): Proceedings of the Pro Mare Symposium on Polar Marine Ecology, Trondheim. 12-16 May 1990. Polar Research 10(l).

Sakshaug. E.. Johnsen. G.. Andresen, K. \& Vernet, M. 1991: Modeling of light-dependent algal photosynthesis and growth: experiments with the Barents Sea diatoms Thalassiosira nordenskioeldii and Chaetoceros furcellatus. DeepSea Res. 38. 415-430.

Skjoldal. H. R. \& Rcy, F. 1989: Pelagic production and variability of the Barents Sea ccosystem. Pp. 241-286 in Sherman. K. \& Alexander. L. M. (eds.): Biomass yields and geography of large marine ecosystems. AAAS Selected Symposium 111 , Westview Press. Inc., Colorado. USA.

Shuman. F. R. \& Lorenzen. C. J. 1975: Quantitative degradaton of chlorophyll by a marine herbivore. Limnol. Oceanogr. 20 , $580-585$

Wassmann. P., Vernet, M. Mitchell. B. G. \& Rey, F: 1990. Mass sedimentation of Phaeocystis pouchetii in the Barents Sea. Mar. Ecol. Prog. Ser. 66. 183-195.

Welschmeyer, N. A. \& Lorenzen. C. J. 1985: Chlorophyll budgets: zooplankton grazing and phytoplankton growth in a temperate fjord and the Central Pacific Gyre. Limnol. Oceanogr. 30,1-21. 